\title{
Asia, Say No to NATO
}

\begin{abstract}
Since the end of the Cold War, NATO has turned from a stabilizing force to a destabilizing force. The Pacific, which has managed to maintain a degree of peace, has no need for the destructive militaristic culture of the Atlantic alliance.
\end{abstract}

Something very dangerous happened a few weeks ago when the North Atlantic Treaty Organisation (NATO) held its meeting in Brussels. In its communique after the meeting on June 14, it identified China as a "systemic challenge" to areas "relevant to Alliance security".

The implicit message was clear: NATO would like to expand its tentacles beyond the Atlantic to the Pacific Ocean. All of us who live close to the Pacific Ocean, especially in East Asia, should be deeply concerned. If NATO comes to the Pacific, it only means trouble for us. Why? Three reasons.

First, NATO is not a geopolitically wise organization. It did a brilliant job in the Cold War, deterring Soviet expansion into Europe. During the Cold War, it was careful and restrained, building up military capabilities and avoiding direct military conflicts.

The Cold War ended 30 years ago. In theory, after "mission accomplished", NATO should have shut down. In practice, it desperately looked for new missions. In the process, it destabilized Europe.

It bears remembering that relations between Russia and NATO used to be much better, so much so that in 1994, Russia officially signed up to the Partnership for Peace, a program aimed at building trust between NATO and other European and former Soviet countries. But things fell apart because NATO rejected Russia's repeated requests to refuse to accept new members in its "backyard". Then, in April 2008, NATO pushed things further, opening the door to membership for Georgia and Ukraine at the Bucharest summit.

As US commentator Tom Friedman noted: "There is one thing future historians will surely remark upon, and that is the utter poverty of imagination that characterized US foreign policy in the late 1990s. They will note that one of the seminal events of this century took place between 1989 and 1992 — the collapse of the Soviet Empire...

Originally published in The Straits Times, June 25, 2021 
Thanks to Western resolve and the courage of Russian democrats, that Soviet empire collapsed without a shot, spawning a democratic Russia, setting free the former Soviet republics and leading to unprecedented arms control agreements with the US. And what was America's response? It was to expand the NATO Cold-War alliance against Russia and bring it closer to Russia's borders."

The result was inevitable. Russia had tried to be a friend of the NATO countries after the Cold War ended. Instead, it was slapped in the face with NATO expansion. Many Western media reports portray Russia as a "belligerent, aggressive actor". They fail to mention that NATO actions generated this response.

A truly dangerous moment surfaced in 2014 when it looked as if NATO was about to encroach into Ukraine with the ouster of its pro-Russian president Viktor Yanukovych by Western-supported demonstrators. For President Vladimir Putin, that was the last straw, and soon after came the seizure of Crimea, which the Russians consider part of their cultural heartland.

The dangers of Western expansion into Ukraine were well known. Dr Henry Kissinger had pointed out that the Ukrainians "live in a country with a complex history and a polyglot composition. The Western part was incorporated into the Soviet Union in 1939 when Stalin and Hitler divided up the spoils. Crimea, 60\% of whose population is Russian, became part of Ukraine only in 1954, when Nikita Khrushchev, a Ukrainian by birth, awarded it as part of the 300th-year celebration of a Russian agreement with the Cossacks. The west is largely Catholic; the east is largely Russian Orthodox. The west speaks Ukrainian; the east speaks mostly Russian. Any attempt by one wing of Ukraine to dominate the other-as has been the pattern-would lead eventually to civil war or break-up. To treat Ukraine as part of an East-West confrontation would scuttle for decades any prospect to bring Russia and the West - especially Russia and Europe-into a cooperative international system”.

Sadly, since 2014, Ukraine has become a divided country. If NATO had shown greater geopolitical restraint, these problems could have been avoided.

The second major weakness of post-Cold War NATO is that its behavior reflects the old adage: If you are a hammer, every problem looks like a nail.

Curiously, during the Cold War, NATO dropped very few bombs on foreign countries. Since the end of the Cold War, NATO has dropped a massive amount of bombs on many countries. Between March and June 1999, NATO bombing campaigns were estimated to have killed 500 civilians in the former Yugoslavia. NATO also dropped several thousand cluster bombs there, despite their use being illegal under the 2010 Convention on Cluster Munitions Treaty.

NATO airstrikes in Libya in 2011 resulted in 7700 bombs dropped, and killed an estimated 70 civilians.

Many of the bombing missions were illegal under international law. I vividly remember having dinner at the home of a former Canadian diplomat in Ottawa when NATO decided to bomb Yugoslav forces in 1999. This Canadian diplomat was deeply worried. Since this military campaign was neither an act of self-defense nor authorized by the United Nations Security Council, it was clearly and technically illegal under international law. 
Indeed, Ms Carla Del Ponte, a former special prosecutor in the International Criminal Tribunal for Yugoslavia, tried to investigate whether NATO committed war crimes in the former Yugoslavia. Even though most NATO countries believe in the sanctity of international law, they applied so much political pressure that Ms Del Ponte could not carry out her investigations.

Even worse, NATO has often started a military campaign and then walked away from the disastrous consequences of its intervention. Libya is a classic example of this. The NATO countries were exultant when Muammar Gaddafi was removed from Libya. However, after the country split apart and became caught up in a civil war, NATO just walked away. Many years ago, a wise former US secretary of state, Mr Colin Powell, warned against such military interventions by citing a common statement in crystal shops: "If you break it, you own it." NATO failed to own the wreckage it left behind.

This leads to the third danger: East Asia has developed, with the assistance of ASEAN, a very cautious and pragmatic geopolitical culture. In the 30 years since the end of the Cold War, NATO has dropped several thousand bombs on many countries. By contrast, in the same period, no bombs have been dropped anywhere in East Asia.

This is therefore the biggest danger we face in NATO expanding its tentacles from the Atlantic to the Pacific: It could end up exporting its disastrous militaristic culture to the relatively peaceful environment we have developed in East Asia.

Indeed, if NATO was a wise, thinking, and learning organization, it should actually be studying the East Asian record-especially the ASEAN record of preserving peace-nand learning lessons from it. Instead, it is doing the opposite, thereby creating real dangers for our region.

In view of the risks to East Asia through the potential expansion of NATO culture, all of East Asia should speak with one voice and say no to NATO.

\footnotetext{
Open Access This chapter is licensed under the terms of the Creative Commons AttributionNonCommercial-NoDerivatives 4.0 International License (http://creativecommons.org/licenses/bync-nd/4.0/), which permits any noncommercial use, sharing, distribution and reproduction in any medium or format, as long as you give appropriate credit to the original author(s) and the source, provide a link to the Creative Commons license and indicate if you modified the licensed material. You do not have permission under this license to share adapted material derived from this chapter or parts of it.

The images or other third party material in this chapter are included in the chapter's Creative Commons license, unless indicated otherwise in a credit line to the material. If material is not included in the chapter's Creative Commons license and your intended use is not permitted by statutory regulation or exceeds the permitted use, you will need to obtain permission directly from the copyright holder.
}

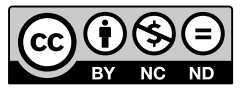

